\title{
Focal Point Pricing: A Challenge to the Successful IMPLEMENTATION OF SECTION 10A (INTRODUCED BY THE Competition AMENDMENT ACT)
}

\author{
Mike Holland \\ PriceMetrics and Gordon Institute of Business Science \\ Jannie Rossouw \\ Department of Economics, University of the Witwatersrand \\ Jessica Staples \\ Attorney of the High Court of South Africa \\ Accepted: March 2015
}

\begin{abstract}
The Competition Amendment Act introduced section 10A, which provides the Competition Commission with the powers to investigate complex monopoly conduct in a market and allows the Competition Tribunal, under certain conditions, to prohibit such behaviour. Although more than five years have elapsed since the Competition Amendment Act was promulgated, this provision has yet to come into force. However, when it eventually does so, it will mark a significant change in South African competition law, as it seeks to regulate firms' consciously parallel conduct. This is coordinated conduct that occurs without communication or agreement, but results in the prevention or substantial lessening of competition. Examples of horizontal tacit coordination practices include price leadership and facilitating practices, such as information exchanges and price signaling. The successful implementation of the amendment poses problems for the competition authorities in assessing the competitive effects of complex monopoly conduct and in providing effective remedies. Oligopoly markets result in mutual interdependent decision-making by firms, which can lead to market outcomes similar to explicit collusion.

However, a further and little noticed issue is that firms in oligopolistic markets have opportunities to use focal points to determine coordinated strategies. This paper explores the nature and role of focal point pricing, which can lead to prices that are above competitive levels. The South African banking industry is used as an example. We find that focal point pricing is difficult to control, making the successful implementation of section $10 \mathrm{~A}$ even more problematic. Moreover, the proposed amendment provides scope for the imposition of structural remedies by the Competition Tribunal, a function that the Competition Tribunal is ill-suited to perform.
\end{abstract}

Key words: Competition Amendment Act, Competition Commission, Competition Tribunal, complex monopoly conduct, focal points, focal point pricing behaviour

JEL: D4, L5

\section{$1 \quad$ Introduction}

This paper analyses potential problems for firms and the competition authorities arising from an amendment to South African competition law introduced by the Competition Amendment Act 1 of 2009 ("Amendment Act"). ${ }^{1}$ This extends the liability for prohibited horizontal practices beyond an agreement or concerted practice to include tacit coordination in certain concentrated market structures and circumstances. One consequence of this amendment will be an increased scrutiny of pricing practices in oligopolistic markets. It is well-known that oligopolists are 'interdependent' in their pricing decisions; the prices they charge are based partly on their competitors' anticipated responses. Recognition of their common interest often leads to less vigorous price competition and prices that are elevated substantially above competitive levels. Examples of these kinds of pricing 
practices are: price leadership; meeting competition clauses, such as matching competitors' prices; most favored customer clauses in contracts; uniform delivered pricing policies; and facilitating practices, such as exchanges of price information and price signalling.

Another pricing policy that will be affected by the amendment is the use of focal points to set and adjust prices. A focal point price is a coordinated price set by two or more sellers without communication that can generate supracompetitive profits. The price coordination arises from a convergence of expectations or mutual understanding of what the appropriate market price should be and it is chosen for its salience, prominence or uniqueness in the market. The sources of focal point prices are market institutions. They include formal institutions such as laws and regulations such as price ceilings (credit card and loan interest rates or fees charged at maximum rates set by law), price floors (minimum wages), market conventions and norms, such as the South African banks' prime overdraft rate fixed at 3,5 percentage points above the South African Reserve Bank's ("SARB") repo rate.

The Amendment Act introduces into South African competition law ${ }^{2}$ the concept of complex monopoly conduct (this will be section 10A of the Competition Act 89 of 1998 ("Act") when the amendment comes into effect). In terms of the Amendment Act, complex monopoly conduct is defined as a situation in which: ${ }^{3}$

- at least 75 per cent of the goods or services in a market are supplied to, or by, five or fewer firms;

- two or more of these conduct their respective business affairs in a conscious parallel or coordinated manner (i.e. co-operation but without agreement between or among themselves); and

- $\quad$ this conduct has the effect of substantially preventing or lessening competition in that market; unless a firm engaging in the conduct can prove that any technological, efficiency or other procompetitive gain resulting from the conduct, outweighs any such effect.

More than five years have elapsed since the promulgation of the Amendment Act, but section $10 \mathrm{~A}$ has still not been signed into force by the President. At this stage, there is no indication of when this will happen.

However, the proposed amendment marks a significant shift in the approach to prohibited horizontal restrictive practices in South African competition law. When this amendment comes into effect, it will bring South African legislation closer to the economic approach of punishing the collusive conduct advocated by antitrust scholars such as Richard Posner (2001) and Louis Kaplow (2011). According to this approach, liability is determined by its effects or market outcomes, whether explicit or tacit, rather than its being based on proof of the existence of an 'agreement'. Economists argue that the decision by a rational, profit-seeking firm to coordinate its activities with its competitors, whether expressly or tacitly, is essentially the same; the firm decides by balancing the benefits from colluding against the costs, including the risk of punishment by competition authorities. As Kaplow (2011) points out regarding explicit or tacit collusive attempts to elevate prices above competitive levels, ' $[\mathrm{t}]$ he harm from price coordination depends most directly on the extent and duration of supracompetitive pricing, not on the means of reaching or maintaining the heightened price'.

The widening of the scope of collusive practices to include 'conscious parallel conduct' is soundly based on economic theory and may act as a deterrent to firms charging supracompetitive prices in highly concentrated markets. However, a number of problems and difficulties arise from the introduction of section $10 \mathrm{~A}$, both in principle and in implementation.

This paper explores and discusses the role of focal point prices as a form of tacit price coordination. It adds to the available domestic literature, as focal points as a pricing strategy have received little attention in South Africa other than in a paper by Demertzis and Viegi (2008) which considers inflation targets as focal points for inflation expectations and pricing behaviour.

This paper is organised as follows: Section two provides a discussion of the legal changes introduced by section 10A. Section three outlines the key economic principles of tacit collusion 
and focal points that are used in a discussion of the effects of the new legislation. Section four examines pricing in the South African banking industry as an example of focal point pricing in South Africa. Section five analyses the likely problems arising from the introduction of section 10A. Section six provides a brief conclusion.

\section{Express and tacit collusion - the changes introduced by section 10A}

Currently in South African competition law, section 4(1)(b) of the Act prohibits cartel conduct arising from 'an agreement between, or concerted practice by firms, or a decision by an association of firms' in a horizontal relationship. Although the scope of the prohibition is clearly circumscribed, 'agreement' is given a broad interpretation that extends beyond enforceable legal agreements. ${ }^{4}$ Furthermore, the scope of the prohibition clearly extends to cooperative or coordinated conduct among firms that falls short of an agreement - the only prerequisite is that the coordinated conduct must be achieved through some form of direct or indirect contact. ${ }^{5}$ In Pioneer Foods, the Tribunal recognised that this contact could take a number of guises, including secret meetings and signalling to competitors in an effort to disguise the true nature of the conduct in the 'guise of normal commercial practices.' 6

It has also been accepted in South African competition law that, where firms exchange competitively sensitive information, this may constitute a facilitating practice for conduct that falls within the scope of section 4(1)(b) of the Act. An example of information exchange that has resulted in the participants being prosecuted for cartel conduct is the investigation initiated by the Competition Commission ("Commission") against a number of petroleum companies and an industry organisation. ${ }^{7}$ The Commission found that the South African Bitumen Association ("SABITA") had been circulating bitumen price-adjusted factor percentages and escalation figures to oil companies on a monthly basis, enabling them to determine what the market was likely to do over the next month in terms of prices.

The Department of Trade and Industry (DTI) (2008) supported the introduction of section 10A. Prior to the introduction of the amendment, it expressed the view that the requirement under the Act that a prerequisite for cartel conduct is the existence of an agreement or some form of contact or facilitating practice between competitors inhibits the Commission's ability to prevent and seek redress for multiple firm coordinated conduct. It viewed the amendment as a means of prohibiting multi-firm conduct that restricts competition to the disadvantage of consumers.

In a plain reading of the section $10 \mathrm{~A}$ amendment, this will allow the Commission to investigate tacit collusion in situations where, in a concentrated industry, the interdependence of major firms leads to coordinated outcomes, even if there is no agreement or reciprocal understanding between these firms. Section 10A applies specifically to firms that conduct their business affairs 'in a conscious parallel' manner. The Amendment Act defines 'conscious parallel conduct' as occurring when 'two or more firms in a concentrated market, being aware of each other's actions, conduct their business affairs in a cooperative manner without discussion or agreement' ${ }^{8}$

Interestingly, there is little international precedent for competition legislation (such as section 10A) that explicitly regulates conscious parallel conduct:

- In the United States of America (US), the US courts have indicated that 'conscious parallelism' is not, on its own, unlawful. ${ }^{9}$ In order to establish collusive conduct, evidence is required that supports the existence of collusive conduct more strongly than the possibility that the firms acted independently (Kovacic, Marshall, Marx \& White, 2011). ${ }^{10}$

- In the European Union (EU), the Treaty for the Functioning of the European Union (TFEU) does not contain a 'complex monopoly' prohibition, but coordinated conduct fails within the scope of article 101. In the Woodpulp II case, the European Court of Justice held that parallel conduct could not be regarded as proof of concertation (or coordinated conduct) unless concertation is the only plausible explanation for the conduct. ${ }^{11}$

- United Kingdom (UK) competition law previously included the concept of a complex monopoly. ${ }^{12}$ However, since the introduction of the Competition Act, 1998 (which is very 
similar to articles 101 and 102 of TFEU) and the Enterprise Act, 2002 (Enterprise Act), this is no longer the case. Although the Enterprise Act does not explicitly provide for complex monopolies, its market investigation provisions provide a mechanism for the investigation of oligopolistic markets (Whish \& Bailey, 2012:582).

\section{Economics of tacit collusion and focal points}

\subsection{Tacit collusion}

The economic theory of collusion focuses on what outcomes are sustainable and the strategy profiles that sustain them (Harrington, 2012). Economists have long known (Chamberlin, 1929, $1933 ;{ }^{13}$ Stigler, 1947) that, in oligopolistic markets, firms recognise their mutual interdependence and may be able to elevate prices substantially above competitive levels without explicit collusion. With the development of game theory, economists now use the theory of non-cooperative games to study coordinated behaviour by firms in oligopolistic markets. In single periods or static, simultaneous games-coordinated action such as price fixing by rational, profit maximising firms is not a Nash equilibrium. ${ }^{14}$ The dominant strategy for all the players is to defect from any cooperation. This 'prisoner's dilemma' arises because, although all the players benefit from coordinating their prices to levels above the non-cooperative level, each firm can increase its profits by cheating on the agreement, lowering its price and obtaining higher sales at the expense of its rivals. Because it is rational for every player to follow a strategy of cheating, all firms will charge prices at the competitive level and be worse off. The outcome of the game is Pareto inferior; all the players would have been better off with a cooperative price.

In dynamic or repeated games, the prisoner's dilemma can be overcome under certain assumptions. ${ }^{15}$ Consequently, cooperative outcomes like price levels elevated above the competitive levels, including prices at the monopoly level, result in a Nash equilibrium (Tirole, 1988:239-276). These outcomes occur for games of both explicit and tacit coordination; economists make no distinction between the type of collusion, whether it arises from an explicit cartel agreement or from tacit collusion, where a mutual understanding exists even though there is no communication.

There are a number of weaknesses in the current state of the game theory analysis of collusion that significantly reduces its usefulness for competition policy. First, while a coordinated outcome is a Nash equilibrium in a repeated game, the 'Folk Theorem' states that, if discount rates are sufficiently low, any equilibrium is possible, from a monopoly outcome with 'perfect' levels of collusion to a non-cooperative, competitive situation (Fudenberg \& Maskin, 1986). ${ }^{16}$ A second major weakness is the possibility of multiple Nash equilibria in a game. Classical game theory provides little guidance to the explanation of the choice of action firms take in these circumstances. ${ }^{17}$ Consequently, given this indeterminacy, the theory of repeated non-cooperative games provides little a priori guidance on horizontal practices such as price fixing as far as policy makers and competition authorities are concerned. Whinston (2006) summarises the issue, maintaining that it is in some sense paradoxical that the least controversial area of antitrust is perhaps the one in which the basis of policy in economic theory is weakest'.

Focal point theory can provide insights in which classical game theory is absent, which leads to a clearer understanding of how firms choose particular coordinated strategies, such as charging prices that are above the competitive levels. Although the idea of focal points is not new (Hume, 1740), focal point theory is based largely on the seminal contribution by Thomas Schelling in his book The Strategy of Conflict (1960). Schelling (1960) developed an analytical framework to explain how people can coordinate their actions with those of others for mutual benefit without communication if they know that others are trying to do the same. Schelling argued that many real problems of coordination and bargaining are resolved with the use of focal points, which are points of convergence for expectations. Finding focal points is a coordination game of strategy in which the interests of the players are convergent: 'It is a behavior situation in which each player's 
best choice of action depends on the action he expects the other to take, which he knows depends, in turn, on the other's expectation of his own' (1960:86), and 'one is trying to guess what the other will guess one's self to guess the other to guess and so on ad infinitum' (1960:93).

In a series of informal experiments, Schelling demonstrated that people successfully coordinate their actions beyond what would be expected by random behaviour. For example, in one of his experiments he asked people in Connecticut where they would meet another person in New York City on a specific day under the following conditions:

You are to meet somebody in New York City. You have not been instructed where to meet; you have no prior understanding with the person on where to meet; and you cannot communicate with each other. You are simply told that you will have to guess where to meet and that he is being told the same thing and that you will just have to try to make your guesses coincide' (1960:56). ${ }^{18}$

The many thousands of meeting places in New York City did not prevent a majority of respondents from managing to meet each other at the Information Booth in Grand Central Station at 12:00. The reason why the respondents chose this location was that it had a strong salience or prominence that led to a meeting of minds or mutual understanding of where to meet in the city. Schelling's findings from his experiments have been confirmed by many other researchers, ${ }^{19}$ including Mehta, Starmer and Sugden (1994a; 1994b), Bacharach and Bernasconi (1997), Crawford et al. (2008), Bardsley et al. (2010) and Isoni et al. (2013).

Economists and other game theorists have tried to formalise Schelling's analytical framework but it sits uneasily within conventional game theory models. Bacharach and Bernasconi (1997) state:

It has become apparent that for many important classes of games traditional game theory is indeterminate, since tightening traditional solution concepts to the limit still leaves multiple solutions. Explaining players' behaviour therefore requires an addition to game theory, a theory of how players select one solution from several that are equally eligible as far as game theory is concerned.

Focal point theory is an attempt to solve some of these problems using a single period pure coordination game or 'matching game' (Bacharach \& Bernasconi, 1997). The game is distinctive to classical game theory because it overcomes the prisoner's dilemma that precludes coordination in a single period simultaneous game. ${ }^{20}$ In the pure coordination game there are two players with the same set of strategies; both get a reward 'if and only if both choose the same strategy and the reward is the same whatever this strategy may be' (Bacharach \& Bernasconi, 1997). In the game, the players reach focal points through the 'labeling' of their possible strategies, which distinguishes each strategy, allows recognition of each strategy and describes the game to each player (Sugden, 1995). Labels which have prominence, salience or uniqueness provide Schelling's 'rule of selection' of a strategy chosen by both players based on what each player thinks the other player will choose.

There is no generally-accepted explanation for how people actually manage to coordinate their actions through focal points. Two alternative approaches have been developed. The first, cognitive hierarchy theory (Camerer, Ho \& Chong, 2004), or level-n theory (Bacharach \& Stahl, 2000), assumes that focal points are reached on the basis of the psychological factors that shape people's preferences for playing particular strategies by default, when there are no other reasons for their choice. Another approach is 'team reasoning', which assumes that each player chooses the decision rule that, if used by all the players, would be optimal for each of them (Sugden, 1993:6989; 1995:45; Bacharach \& Bernasconi, 1997). Empirical evidence is mixed, suggesting that there is no single explanation, thereby confirming Schelling's opinion that people find focal points in a wide variety of ways. Schelling rejects the opinion that these methods can be explained by a single formal theory (Bardsley, Metha, Starmer and Sugden, 2010).

Using focal points to coordinate actions does not always work or work well. Schelling points out that a prominent or conspicuous action required for successful coordination may not exist, or 
else it 'depends on time and place and who the people are' (Schelling, 1960).

\subsection{Focal point pricing}

Focal point theory can be used to explain how firms coordinate their strategies to set and adjust their prices in a wide variety of markets. Certain prices can have a salience, prominence or obviousness that allows a meeting of minds to establish prices that are higher than would be obtained through independent pricing strategies. Specific strategies include price lining, standard mark-ups on costs, suggested or recommended resale prices, import parity prices, and price ceilings and floors.

The choice of focal point business strategies for pricing is largely influenced by market institutions. Institutions are 'the rules of the game in a society, or more formally the humanly devised constraints that shape human interaction' (North, 1990). Institutions can be formal, with laws, regulations and other rules or informal, with conventions, norms, customs and codes of behaviour. By reducing uncertainty in the economic, social and political environment, they provide a guide to human interaction and promote human coordination and cooperation. Institutions can apply to the economy and society as a whole or to specific markets. Market institutions can yield focal points, whereby firms can coordinate their pricing behaviour. These focal points may be generated by the market norms, conventions, and culture embedded in the behaviour of firms in an industry. Laws and regulations in specific markets that determine price ceilings or floors, rules that shape regulated prices and bidding for public sector contracts can also provide opportunities for coordinated conduct that reduces competition in a market.

Price lining is pervasive in business, not just in highly concentrated markets. Focal point prices, such as round numbers, for example, R20 or R500, and odd numbers like R199,95 can keep prices and profit margins at supracompetitive levels (see, for instance, Scherer, 1967).

The concept also applies to discounts on list prices. A common practice is to set discount rates at round numbers fairly far apart, for instance, 10 per cent and 20 per cent. By setting discounts in this way, firms discourage each other from granting deeper discounts or chiseling discounts from industry standard levels.

Another major source of focal point prices arises from cost plus pricing strategies, the most common form of price behaviour of firms. ${ }^{21}$ Over time, conventions or norms develop in industries where firms recognise the most 'appropriate' mark-up over cost ('rule of thumb') pricing policies to sustain profitability at 'satisfactory' levels. These pricing practices are applicable particularly in industries producing standard prices or where unit costs vary little between firms. The South African banks' practice of adopting the market norm of pricing their prime overdraft rate at 3,5 percentage points above the SARB's repo rate is an example of such behaviour.

Recommended or suggested prices provide focal points for setting prices. Firms using these practices are providing a salient price to their distributors or retailers indicating what the appropriate price should be, and the prices can be set to yield supracompetitive returns for both the firm and its resellers. The downstream firms will recognise the appropriate price and could also have some insight into what price various firms expect others, including themselves, to charge. No communication is needed for the recommended resale price to be understood as the 'correct' price to be charged in the downstream market.

Government laws and regulations can also act as focal points for price setting. In some cases, firms use price ceilings as a form of 'regulatory capture' to charge prices above the levels they would otherwise independently set in the market.

There is substantial empirical evidence of the use of focal point prices by firms. Scherer (1980) found that price lining is widespread at the retail level in the US and 'most consumer goods manufacturers are well aware that adherence to accepted pricing points facilitates coordination and discourages price warfare'. Empirical studies have confirmed that price ceilings determined by government legislation and regulations can act as focal points (Sheahan, 1961).

Knittel and Stango (2003) maintain that, in the US credit card market, 
[t]acit collusion at non-binding state-level ceilings was prevalent during the early 1980s but that national integration of the market reduced the sustainability of tacit collusion by the end of the decade. The results highlight a perverse effect of price regulation.

Another study of loan markets in the United States by DeYoung and Phillips (2006) established that 'over time, payday loan prices have gravitated towards the legislated price ceiling'.

In Europe, Eriksson (2004) studied the effects of deregulation in the Swedish dental market, saying that the 'Swedish government was worried that the ceiling was serving as a focal point for implicit price collusion' and that 'a removal of the price ceiling could lead to increased competition and lower prices'. In the Netherlands, Faber and Janssen (2011) investigated the effects of oil companies suggesting petrol and diesel prices to their retailers and speculating whether this created focal points for the coordination of actual prices charged by retailers. Faber and Janssen concluded that the suggested prices reduced the uncertainty for retailers when it came to competitors' price changes and helped firms to form mutually consistent expectations of their pricing strategies.

Elsewhere, Ma (2007) investigated price ceilings in the flour market in Taiwan, and discovered evidence that firms in the market set prices 'above competitive equilibrium levels during most of the regulation period' and that 'observations on prices also show that all flour firms set their prices equal to ceilings, without exception'.

An interesting example of how a market convention has become a focal point is the practice by the South African banks of setting interest rates according to the repo rate, which is explained briefly in the next section.

\section{Pricing practices by South African commercial banks in setting the prime overdraft rate}

The five largest South African banking groups account for 92,7 per cent of the banking sector assets (Bank Supervision Department, 2012). This concentration of assets implies that the conduct of the institutions might fall within the scope of section 10A when this comes into force.

Further, South African banks may fall within the scope of section 10A in that two or more firms (in this instance, the commercial banks) conduct their business affairs as a conscious parallel or in a coordinated manner, without agreement among themselves, insofar as they adjust interest rates in a concerted fashion.

South Africa has a long history of banks acting in unison on interest rate decisions. This can be explained in the main by (i) short- and long-dated interest rates following broadly the same trend (albeit at different levels, depending on the yield curve), and (ii) the link between the refinancing rate of the central bank and the prime overdraft interest rate (De Kock Commission, 1985). ${ }^{22}$ Commercial banks all link their prime overdraft rates at the same margin to the refinancing (repo) rate of the central bank. Currently, this margin is 3,5 percentage points.

This convention serves three functions. First, it ensures the immediate operationalisation ${ }^{23}$ of interest rate decisions by the SARB (upwards or downwards) in the financial markets, implying that the central bank knows beforehand what the effect of an interest rate policy decision on market rates will be. Secondly, it ensures that rates move in a concerted way with the movement in the repo rate, thereby reflecting the term structure of rates according to liquidity preference. Thirdly, as South Africa follows the classical approach of a liquidity shortage to operationalise interest rate decisions (commercial banks have a liquidity shortage and have to refinance this shortage at the repo rate at the central bank), the repo rate is the marginal cost of funding of commercial banks.

This is not the only margin based on the repo rate of the central bank. In the Regulations promulgated under the National Credit Act (2005), all prescribed maximum interest rate charges are linked to the repo rate of the central bank. As a case in point, the maximum permissible rate on mortgage agreements is stated as (repo rate $\mathrm{x} 2.2)+5$ per cent per year. ${ }^{24}$ 


\section{Anticipated impact of section 10A}

There is general agreement among competition policymakers and economists that complex monopoly conduct or tacit coordination in highly concentrated markets can harm economic welfare by preventing or reducing competition. There is also a broad consensus among economists that tacit collusion can have the same or similar effects on competition as those of explicit collusion. Yet despite these concerns, competition law has, in many jurisdictions, distinguished, for the purposes of establishing liability, between explicit collusion based on an 'agreement' and tacit collusion. The decision to extend liability to tacit collusion in highly concentrated markets therefore represents a significant shift in competition policy that will distinguish South African competition law from many other jurisdictions.

\subsection{Requirements for a findling under section 10A}

Under section 10A the Commission will be able to investigate a market in which it has reason to believe that complex monopoly conduct exists. ${ }^{25}$ Once its investigation is complete, the Commission will be able to apply to the Tribunal for a declaratory order. In order to obtain this order, the Commission will have to satisfy the Tribunal that:

- at least one of the firms has a minimum of 20 per cent of the market and has engaged in complex monopoly conduct (as defined above); and

- the conduct of the firms has resulted in: (i) high entry barriers to that market; (ii) exclusion of other firms from the market; (iii) excessive pricing in that market; (iv) refusal to supply other firms in that market; or (v) other market characteristics that indicate coordinated conduct. ${ }^{26}$

If the Tribunal is satisfied that the Commission has established the above requirements, it will be able to make an order that either prohibits the conduct or imposes conditions that will mitigate or ameliorate the effect of the complex monopoly conduct on the market. If the firm contravenes this order, its conduct in doing so will constitute a prohibited practice in terms of the Act. ${ }^{27}$

\subsection{Enforcement of section 10A}

Unlike cartel conduct, which is per se prohibited by section 4(1)(b) of the Act, complex monopoly conduct will not be per se prohibited. As a result, the threshold of proof for tacit collusion or complex monopoly conduct will be substantially higher than for explicit collusion. In order to establish complex monopoly conduct, the Commission will have to prove that the conduct will have an anti-competitive outcome that cannot be justified by efficiency, technology or procompetitive gains. Furthermore, the Commission will have to show that the conduct will result in:

- $\quad$ high entry barriers to that market;

- exclusion of other firms from the market;

- $\quad$ excessive pricing within that market;

- refusal to supply other firms within that market; or

- other market characteristics that indicate co-ordinated conduct.

The competition authority's task of establishing that conduct meets the requirements of section $10 \mathrm{~A}$ is consequently daunting. It will require an assessment of the relevant market; a detailed calculation of the market shares of all the firms in the defined market; a determination that the conduct is conscious parallel conduct rather than independent decision-making in a market where firms recognise their mutual interdependence; and a detailed assessment of whether market outcomes are uncompetitive, based on an investigation of market structure, conduct and performance.

Even if the Commission succeeds in discharging its burden of proof and establishes the requirements for satisfying the Tribunal that it should make an order confirming that one or more firms have engaged in complex monopoly conduct, the Tribunal is empowered to address this conduct only by making an order that deals with the effect of the complex monopoly conduct on the market. The Tribunal is not empowered to impose any sort of penalty on the firms for 
engaging in this conduct. Only if the firms subsequently contravene this order is the conduct considered to be a prohibited practice for which a firm would be liable for an administrative penalty.

\subsection{Challenges in the application of section $10 \mathrm{~A}$}

The broad scope of the Commission's investigative mandate under section 10A (as described above) is almost equivalent to a market inquiry, except that the investigation is directed against the conduct of specific firms (rather than a market as a whole) and, if the Commission were to succeed in establishing complex monopoly conduct, the firms involved could be held accountable for this conduct (if a firm subsequently contravenes a declaratory order by the Tribunal in relation to the conduct). Given the potentially serious consequences for firms that are accused of complex monopoly conduct, the scope of section 10A is arguably incomplete, arbitrary, and discriminatory. The limitation of complex monopoly conduct is based on arbitrary market shares and the number of firms in the market is not supported by economic theory. It also ignores the fact that tacit collusion can be a harmful feature of many less concentrated markets. Jacquemin and Slade (1988) point out that tacit collusion can exist in any market:

...the multiplicity of equilibria is one of the problems associated with the repeated-game approach. Instead of providing us with a theory of oligopoly, it can explain all possible behaviors. Moreover, it even suggests that almost all industries will be collusive almost all of the time.

It could be argued that limiting the scope of section 10A to highly concentrated markets based on the criteria in section 10A(1) would cover most of the serious cases of tacit collusion. However, this ignores the fact that less concentrated markets may harm welfare to the same extent as those falling within the scope of the section 10A prohibition.

A general problem for the successful implementation of section $10 \mathrm{~A}$ is whether the conduct of affected firms would fall within the wide scope of the anti-competitive outcomes set out in section $10 \mathrm{~A}(4)(\mathrm{b})$. Some of the criteria appear broad and ill-defined. For example, what is considered a 'high' barrier to entry into the market and how could it be remedied in practice? Many barriers to entry into an industry are structural rather than being a result of the conduct of firms in the market.

In particular, section 10(A)(4)(b)(iii), which refers to excessive pricing as an indicator of an anti-competitive effect of complex monopoly conduct, is likely to create considerable uncertainty among the firms affected. The Commission and Tribunal will be required to determine what a competitive price is in the market and what elevation above such a price is considered 'excessive'. ${ }^{28}$ The result is that the pricing policies of all firms will become vulnerable to the uncertainty of being considered anti-competitive. This aspect of the amendment poses particular challenges in the South African banking industry, as is explained above. Actions by the competition authorities in respect of banks could increase uncertainty and consequently financial instability in domestic financial markets.

Furthermore, if the Tribunal were to impose a behavioural remedy to reduce prices, the Tribunal would be acting as a price regulator. This is a function which the Tribunal is ill-suited to perform, as it involves acting as an instrument of industrial or trade policy rather than an adjudicator of competitiveness in a market.

A further issue of concern is the broad criterion of establishing an anti-competitive effect in section $10 \mathrm{~A}(4)(\mathrm{b})(\mathrm{v})$ that states 'other market characteristics that indicate co-ordinated conduct'. In principle, this implies that any form of conduct in a market is open to scrutiny, restriction or prohibition. This is likely to create high levels of uncertainty for affected firms and could, for example lead to lower levels of investment and employment in the industry.

An additional challenge is that of determining whether 'conscious parallel conduct' exists in a market. There is general agreement that, in highly concentrated markets, firms recognise their mutual interdependence in their decision-making. There are incentives to coordinate actions to reduce competitive pressures in their market and parallel conduct may indicate cooperative interdependent strategies in the market. However, that same market outcome can arise, not by 
interdependent, but by independent actions. If prices go up in a market in a parallel way and there is no explicit collusion, the increase could be attributed to coordinated decisions on the part of firms. However, it may occur because one firm raises its price independently, hoping or expecting that its competitors will also raise their prices. The competitors independently realise that their best response to the increase in the firm's prices is to raise their own. The result is a noncooperative Nash equilibrium whereby each firm's strategy is the independently determined best response to the actions of other firms.

The danger of perceiving parallel behaviour as being the result of coordinated action is overcome to some extent by some competition authorities requiring a 'parallelism plus' rule, according to which tacit collusive conduct is discerned by some facilitating practice that cannot be explained except as a coordinating device. Section 10A does not require a 'plus' factor for the establishment of conscious parallel conduct (although the authorities will need to establish a set of pre-defined criteria to establish the existence of complex monopoly conduct). It is therefore unclear how the authorities will determine conscious parallel conduct given that the same market outcomes (including the outcomes of section 10A(4)(b)) can arise from non-cooperative strategies while recognising mutual interdependence.

The difficulties inherent in the application of section 10A can be shown by considering price leadership strategies. Economists classify price leadership into three types: dominant firm, barometric and collusive, all of which can lead to prices being elevated above competitive levels. In a dominant firm leadership model with standardised products the dominant firm sets its price and output according to its own interests and expects other small firms to meet residual demand in the market at its price. If the dominant firm's objective is short-term profit maximisation, ${ }^{29}$ market prices will be above competitive levels but below monopoly levels. Prices will also change in a parallel fashion. When the dominant firm changes its prices, the smaller firms, as price takers, will also adjust their prices. The competition authorities' resulting concern about this market behaviour is the market power of the dominant firm rather than collusion. In this example, there is no price coordination; the dominant firm sets prices in the market and the smaller firms act independently in their own best interests, with no influence on prices.

\subsection{Section 10A and focal point pricing}

The difficulties experienced by firms and the competition authorities in applying section 10A are particularly applicable to focal point pricing. This involves coordinated pricing by firms in a market without communication. As such, this is conscious parallel conduct as defined in section $10 \mathrm{~A}$. Focal point prices in many market circumstances can result in prices being set at elevated levels in comparison with prices determined by independent decisions by firms.

Competition authorities and policy-makers have identified the issue. In its Guidelines on Vertical Restraints (2010), the European Commission states: 'The possible competition risk of maximum and recommended prices is that they will work as a focal point for the resellers and might be followed by most or all of them and/or that maximum or recommended prices may soften competition or facilitate collusion between suppliers'. They state further that

[a]n important factor for assessing possible anti-competitive effects of maximum or recommended resale prices is the market position of the supplier. The stronger the market position of the supplier, the higher the risk that a maximum resale price or a recommended resale price leads to a more or less uniform application of that price level by the resellers, because they may use it as a focal point. They may find it difficult to deviate from what they perceive to be the preferred resale price proposed by such an important supplier on the market.

In its publication Roundtable on Vertical Restraints for On-Line Sales, the OECD takes a similar view:

In downstream markets similar price arrangements, even if [these] do not impose the retail price, may provide focal points to retailers and therefore increase their ability to coordinate on higher more profitable prices and maximum or recommend resale prices are generally 
considered to raise weak competition concerns. In principle they could create focal points that might facilitate coordination among retailers. ${ }^{30}$

The general criticisms of section 10A outlined above also apply to focal point prices. A price set by focal point reasoning can occur in a wide range of markets, certainly in markets less concentrated than those affected by section 10A. Consequently, it is arbitrary and discriminatory to assign liability to one set of markets and not others, where the harm may be equivalent.

The authorities also have to identify whether firms' pricing policies involve focal points. Are products in a highly concentrated market priced at a round or odd number (say R500 or R199,95? Or are they based on a standard mark-up in an industry of (say) 50 per cent, set at a maximum regulated level, focal point prices or are they independently determined? Are suggested or recommended resale prices or import parity prices focal point prices? Or are they also independently determined by competitive pressures in a market? Likewise, is focal point pricing in the South African banking industry the result of operationalising the monetary system or coordinated conduct? These are probably intractable practical problems for the Commission and Tribunal to overcome.

Equally important is the issue of suitable remedies to restrict or prohibit focal point prices in highly concentrated markets. Ordering firms to change their pricing practices, such as price lining and cost plus pricing, which are deeply entrenched in an industry's informal institutions, is probably an impossible task. To do so would be asking firms to act irrationally, i.e. asking them not to take into account their competitors' prices when setting their own prices. Such orders by the Tribunal are probably impossible to implement effectively. They could also lead to inefficiencies in their markets. Another way is price regulation by setting prices at competitive levels (at marginal cost) below their focal points. This is unlikely to be a viable solution, given the problems of estimating the competitive price and the lack of inclination on the part of competition authorities to act as price regulators. Ordering structural remedies like a break-up of firms into smaller units is also unlikely to succeed, as focal point price reasoning will probably continue in the now less concentrated market. The problems inherent in these approaches make the implementation of section 10A extremely difficult and hazardous in terms of economic welfare.

\section{Conclusions}

This paper augments the available domestic literature by considering an aspect of pricing in oligopolistic markets that has received scant attention in South Africa. Focal point theory can be used to explain how firms coordinate their strategies to set and adjust their prices in a wide variety of markets. The choice of focal points for pricing strategies is influenced largely by market institutions, as these dictate 'the rules of the game' in business conduct and social behaviour. Laws and regulations pertaining to price ceilings or floors, rules that shape regulated prices and bidding for public sector contracts can also provide opportunities for coordinated conduct that reduces price competition in a market. One such example is the South African banking industry where focal point pricing practices are commonly used.

This paper has explored the consequences of the section $10 \mathrm{~A}$ amendment in the context of pricing practices in oligopolistic markets, particularly in relation to focal point pricing. This amendment is not yet in force (although five years have elapsed since the Amendment Act was promulgated), but it marks a significant shift in the approach to coordinated practices in South African competition law. If it comes into effect, the section 10A amendment will widen the scope of restrictions on conduct among firms in a horizontal relationship to include coordinated conduct where there is no evidence of direct or indirect communication among competitors.

The formal regulation of conscious parallelism broadens the means available to the competition authorities to combat anti-competitive coordinated conduct. However, the overly broad scope of the provision is also likely to catch conduct that in reality is not harmful to economic welfare (socalled false negatives). This is particularly the case when it comes to focal point pricing. Focal point prices in many market circumstances can result in prices being set at elevated levels in 
comparison with prices that are independently determined by firms. As such, these are likely to be under scrutiny when the section 10A amendment comes into effect. The amendment also provides scope for the imposition of structural remedies by the Tribunal. Should the Tribunal impose behavioural remedies to reduce prices, it would be acting as a price regulator, a function which it is ill-suited to perform. Consequently, if section 10A comes into effect, it may raise more concerns (such as uncertainty and potentially harmful economic effects in oligopolistic industries, such as the banking industry), than it is likely to solve.

\section{Endnotes}

1 Although the amendment has been promulgated, it has not yet been signed into law

2 Section 4 of the Amendment Act.

3 Section $10 \mathrm{~A}(1)$.

4 In The Competition Commission v Pioneer Foods (Pty) Ltd, the Competition Tribunal ("Tribunal”) referred with approval to the European Commission's decision in the British Sugar case (British Sugar PLC (1999) OJ L76/1 para 66), which indicated (as paraphrased by the Tribunal) that 'an agreement does not have to be made formally or in writing, and no expressed sanction or enforcement measures need be involved, it is enough that the undertakings in question should have expressed their joint intention to conduct themselves in the market in a specific way' (The Competition Commission $v$ Pioneer Foods (Pty) Ltd[2009] 2 CPLR 323 (CT) para 35).

5 Section 1(1)(vi) of the Act.

6 Pioneer Foods supranote 4, paras 32 and 34.

7 Namely Chevron, Engen, Shell, Total, Masana, Sasol, Tosas and SABITA

8 Section $10 \mathrm{~A}(2)$.

9 Brooke Group Ltd v Brown \& Williamson Tobacco Corp 509 US 209227 (1993).

10 Williamson Oil Co v Philip Morris USA 346 F3d $1297\left(11^{\text {th }}\right.$ cir 2003) at 1300.

11 A. Ah/strom Osakeyhtio e.a. (Woodpulp II) (1993) ECR I-I307 para 71.

12 Most recently, under the Fair Trading Act, 1973. This has been repealed and replaced by the Competition Act, 1998 and Enterprise Act, 2002

13 Chamberlin (1929) argues that in an oligopolistic market of identical firms and homogeneous products, the firms in the industry would charge the monopoly price, the price that maximises industry profits. Quoted by Tirole (1988:240).

14 A Nash equilibrium is a solution to a game. It is a set of actions (strategies) by players in the game if none of the players has an incentive to deviate from their choices, given the actions of all the other players. Therefore, for each player, the choice is the best response to the actions of other players and there is no action with a better pay-off.

15 The assumptions are games with an infinite horizon or uncertain horizon. Repeated games with fixed periods still yield a non-cooperative Nash equilibrium.

16 Fudenberg and Maskin (1986:533), 'The Folk Theorem asserts that any individually rational outcome can arise as a Nash equilibrium in infinitely repeated games with sufficiently little discounting'.

17 Mixed games in which firms play random strategies can yield a unique Nash equilibrium.

18 Other games included coin tossing and choosing heads or tails, choosing numbers, military occupation and voting games.

19 In an informal experiment by one of the authors, people were asked where they would meet in Sandton City, Johannesburg on a specific day when they could not communicate with that person to arrange a place to meet. The majority chose the Nelson Mandela Statue in Sandton Square.

20 Although he uses a one-period game, Schelling allows the players of the game some awareness of how similar games have been played in the past by themselves or others (Sugden \& Zamarrón, 2006).

21 There is widespread evidence. For example, in the UK (Greenslade \& Parker, 2012) and in South Africa (Govender, 2012).

22 See De Kock Commission (1985).

23 'Operationalise' in this sense means the actual implementation by market participants of policy decisions.

24 In this instance 5 per cent means 5 percentage points.

25 Section $10 \mathrm{~A}(3)$. Section $10 \mathrm{~A}$ provides that the Commission may investigate conduct that it believes to be complex monopoly conduct without initiating or receiving a complaint in terms of Chapter 5 of the Act.

26 Section $10 \mathrm{~A}(4)$.

27 Section $10 \mathrm{~A}(5)$ and section $10 \mathrm{~A}(6)$

28 The difficulties in determining an excessive price under section 8(a) of the Act in recent cases before the Tribunal are a guide to the likely future problems of assessment.

29 A dominant firm that believes its short-term profit maximisation will lead to an expansion of output by fringe firms may prefer a strategy of limit pricing to maximise long-term profits.

30 Organisation for Economic Co-operation and Development, Directorate for Financial and Enterprise Affairs, Competition Committee Report on Roundtable in Vertical Restraints for On-Line Sales (2013) DAF/COMP(2013)1.

\section{References}

BACHARACH, M. \& BERNASCONI, M. 1997. The variable frame theory of focal points: An experimental study. Games and Economic Behavior, 19(1):1-45.

BACHARACH, M. \& STAHL, D.O. 2000. Variable-frame level-n theory. Games and Economic Behavior, 33(2):220-46. 
BANK SUPERVISION DEPARTMENT. 2012. Annual Report 2012. South African Reserve Bank:28. BARDSLEY, N., MEHTA, J., STARMER, C. \& SUGDEN, R. 2010. Explaining focal points: Cognitive hierarchy theory versus team reasoning. Economic Journal, 120(543):40-79.

CAMERER, C.F., HO, T.H. \& CHONG, J.K. 2004. A cognitive hierarchy model of games. Quarterly Journal of Economics, 119(3):861-98.

CHAMBERLIN, E. 1929. Duopoly: Value where sellers are few. Quarterly Journal of Economics, 43 : 63-100.

CHAMBERLIN, E. 1933. The theory of monopolistic competition. Cambridge, Mass: Harvard Business Press.

COMPETITION ACT 89 OF 1998 (AS AMENDED). Government Gazette No. 19412. 30 October 1998. COMPETITION AMENDMENT ACT 1 OF 2009. Government Gazette No. 32533. 28 August 2009.

CRAWFORD, V.P., GNEEZY, U. \& ROTTENSTREICH, Y. 2008. The power of focal points is limited: Even minute payoff asymmetry may yield large coordination failures American Economic Review, 98(4):1443-58

DE KOCK COMMISSION. 1985. Final report of the Commission of Inquiry into the monetary system and monetary policy in South Africa (De Kock Commission) RP70/1984 106.

DEMERTZIS, M. \& VIEGI, N. 2008. Inflation targets as focal points. International Journal of Central Banking, 4(1):55-87.

DEPARTMENT OF TRADE AND INDUSTRY. 2008. Presentation to the Select Committee of Foreign and Economic Affairs.

DEYOUNG, R. \& PHILLIPS, R.J. 2006. Strategic pricing of payday loans: Evidence from Colorado, 20002005. Indiana State University Working Paper, No. 2006-WP-05.

ERIKSSON, R. 2004. Testing for price leadership and for reputation goods effects: Swedish dental services. Swedish Institute for Social Research (SOFI), Stockholm University, Working Paper 5/2004.

EUROPEAN COMMISSION. 2010. Guidelines on vertical restraints commission notice C 2365.

ENTERPRISE ACT, 2002. N0. 1369.

FABER, R.P. \& JANSSEN, M.C.W. 2011. On the effects of suggested prices in gasoline markets. Working Paper. CPB Netherlands Bureau for Economic Policy Analysis. Department of Competition and Regulation. FUDENBERG, D. \& MASKIN, E. 1986. The folk theorem in repeated games with discounting or with incomplete information. Econometrica, 54(3):533-554.

GOVENDER, N. 2012. Price setting behaviour of manufacturing firms in South Africa. MBA Research Report, Gordon Institute of Business Science, University of Pretoria.

GREENSLADE, J.V. \& PARKER, M. 2012. New insights into price-setting behaviour in the U.K: Introduction and survey results. The Economic Journal, 122 (February):1-14.

HARRINGTON, J. 2012. A Theory of Tacit Collusion. John Hopkins University Working Paper.

HUME, D. 1740. A treatise of human nature, Book 3, part 2, section 1-3. Quoted in R Sugden, Spontaneous Order (1989). Journal of Economic Perspectives, 3(4):85-97.

ISONI, A., POULSEN, A., SUGDEN, R. \& TSUTSUI, K. 2013. Focal points in tacit bargaining; experimental evidence. European Economic Review, 59:167-188.

JACQUEMIN, A. \& SLADE, M.E. 1988. Cartels, collusion and horizontal mergers. In R. Schmalensee and R. Willig (eds.) Handbook of industrial organization (Volume 1). North-Holland: Amsterdam.

KAPLOW, L. 2011. Direct versus communication-based prohibitions on price fixing. Harvard Law School Paper, No.703 2.

KAPLOW, L. 2013. Competition policy and price fixing. New Jersey: Princeton University Press.

KNITTEL, R.K. \& STANGO, V. 2003. Price ceilings as focal points for tacit collusion: Evidence from credit cards. American Economic Review, 93:1703-1729.

KOVACIC, W.E., MARSHALL, R.C., MARX, L.M. \& WHITE, H.L. 2011. Plus factors and agreement in antitrust law. Michigan Law Review, 110:393.

MA, T-C. 2007. Import quotas, price ceilings, and pricing behavior in Taiwan's flour industry. Agribusiness, 23:1-15. 
MEHTA, J., STARMER, C \& SUGDEN, R. 1994a. The nature of salience: An experimental investigation. American Economic Review, 84(3):658-73.

MEHTA, J., STARMER, C. \& SUGDEN, R. 1994b. Focal points in pure coordination games: An experimental investigation of pure coordination games. Theory and Decision, 36(2):163-185.

NATIONAL CREDIT ACT 34 OF 2005. Government Gazette No 28664. 31 May 2006.

NORTH, D.C. 1990. Institutions, institutional change and economic performance. Cambridge: Cambridge University Press.

POSNER, R.A. 2001. Antitrust law (2 ed.) Chicago: University of Chicago Press.

SCHELLING, T.C. 1960. The strategy of conflict. Cambridge, Mass: Harvard University Press. SCHERER, F.M. 1967. Focal point pricing and conscious parallelism. Antitrust Bulletin, 12 (Summer): 495-503.

SCHERER, F.M. 1980. Industrial market structure and performance (2 ed.) Boston: Houghton Mufflin. SHEAHAN, J. 1961. Problems and possibilities of industrial price control: Postwar French experience. American Economic Review, 51:345-359.

STIGLER, G.J. 1947. The kinky oligopoly demand curve and rigid prices. The Journal of Political Economy, LV:432-449.

SUGDEN, R. 1993. Thinking as a team: Towards an explanation of nonselfish behavior. Social Philosophy and Policy, 10(1):69-89.

SUGDEN, R. 1995. A theory of focal points. Economic Journal, 105(430):533-50.

SUGDEN, R. \& ZAMARRÓN, I.E. 2006. Finding the key: the riddle of focal points. Journal of Economic Psychology, 27(5):609-21.

TIROLE, J. 1988. The theory of industrial organization. Cambridge, Mass: MIT Pres.

TREATY OF THE FUNCTIONING OF THE EUROPEAN UNION. 2012. OJ C.326. Article 101.

WHINSTON, M.D. 2006. Lectures on antitrust. Cambridge, Mass: MIT Press.

WHISH, R. \& BAILEY, D. 2012. Competition Law (7 ${ }^{\text {th }}$ ed.) Oxford: Oxford University Press. 